\title{
Image language and the language of images: A closer examination of videography in cross-cultural school studies
}

Research in Comparative \& International Education 2015, Vol. I0(3) 383-393

(C) The Author(s) 2015

Reprints and permissions: sagepub.co.uk/journalsPermissions.nav DOI: $10.1177 / 17454999 / 5580636$ rci.sagepub.com (SAGE

\section{Juliane Engel}

Friedrich-Alexander-University Erlangen, UK

\begin{abstract}
This paper evaluates the development of new cultural theories utilizing video-based analysis. For this purpose, a multi-methods research design, combining videographies, group discussions and surveys, was applied. A video sequence showing a clip of a 10th grade class at Ramja Public School in Pusa Road in Delhil provides the basis for a discussion regarding what imaging material really visualizes, and pointing out the invisible pedagogic concepts that are entwined with interpretation. Furthermore, this paper investigates the concept of culture(s) in the analysis of class situations, taking a special interest in the culture of (moving) images. Therefore the research question is: How do videographies as moving images generate meaning that is distinct from language? The paper will hint at the phenomenon of invisible inner concepts, which to date, have been neglected, in the analysis of videographies.
\end{abstract}

\section{Keywords}

Cultural Theory, Visual anthropology, Mixed methods Research, (invisible) pedagogic concepts of learning

\section{Introduction: images of culture and the culture of images}

Pictures are omnipresent, they have always played a central role in our lives. Pictures and pictorial stories build our understanding of reality, and they determine our self-perception. Humans are being confronted with images from the very moment when they come into existence, with visually perceived images, with imaginations, with fantasies, with memories. They affect us directly, consciously or unconsciously. (Stenger and Fröhlich, 2003: 7)

Videography, therefore, is a common means used in comparative cross-cultural education studies to analyse classroom situations, learning and educational cultures (Dinkelaker and Herrle, 2009; Pauli and Reusser, 2006; Tobin, 2007; Tobin and Hsueh, 2007). Yet to date, the focus of these 
studies has been on quantitative enquiry, i.e. establishing pupils' and teachers' speaking time and learners' measurable successes. That is, research has emphasized quantifiable performance for the purpose of the didactic employment of media like whiteboards, among others. An example of this international research tradition is the video analysis of a class situation presented in a PISA- and TIMMS-study (Pauli and Reusser, 2006). These comparative cross-cultural studies often fail to consider something that it is contended leads to their deficiency; that is, the role of the picture itself, which is at the core of this research method. Images take effect as mental images, engaging in a dynamic relationship with the material images with which they interact, as observed by Immanuel Kant (1790/1998).

In the extended, historical and anthropological conception of images, this paper, which is based on videography, finds different forms of images that influence comparative cross-cultural education studies (Wulf and Hüppauf, 2006). To put this in the words of Tobin and Hsueh:

[W]e should break free of educational videos' roots in instructional films and observational analysis, and add to the goals of documenting and informing the goals of provoking self-reflections, challenging assumptions, creating things of beauty, entertaining, and giving pleasure. (...) And these more aesthetically pleasing, entertaining and compelling videos are not just pleasing and entertaining - they are also make for more effective social science. (Tobin and Hsueh, 2007: 77)

To attain this freedom, this paper presents videographies of school lessons, showing images, in this case as a metaphor, gaining strong momentum with the interaction between a teacher and her pupils. Before taking a closer look at this example, the impact of mental and material images will be reflected on. Assuming that learning itself is invisible, it is suggested that in the process of analysing education-videography, it is a researcher's ideas about learning processes that are stimulated in particular. As they become aware of this, it is their ideas that become visible through analysis (Hüppauf and Wulf, 2009; Michaels and Wulf, 2011). Therefore, their ideas must be seen in a dynamic relationship with the visual data. The focus is now on the mental images that researchers develop when practicing research in the field of learning; a phenomenon which is not easily accessible.

When using video recording in cross-cultural education studies, it is important to be aware of the role of the research method as well as that of the researcher. Such studies need to consider the implicit pictures present in recordings, which reveal something about the researcher, creating a certain reality or image of another culture through comparison with the researcher's own culture. A pedagogic image of anthropology, as this study perceives it, offers this potential through culturecomparative, video-based studies: 'Thick views of education in other countries/cultures help us imagine how education can be different and thus denaturalize how we see education in our own culture Tobin (2007: 337). Taking this perspective, it is suggested that there is no other culture speaking of an essentialized category - that is, the researcher produces a culture of images by filming and analysing a supposed culture. Images, as well as videography, in the form of moving images, cannot be considered linear media. They do not provide a single and valid message concerning a specific 'other' culture, or information about schools and education in other countries; whereas, language delivers information in a linear and chronological order, and images, due to their complex structure, provide multiple messages simultaneously. For example, they tell us something about pupil A chatting with pupil B, while the teacher draws a map on the white board and pretends not to hear the noise. The sequence of images hereby enables a complex analysis of pupil-teacher interactions.

However, each researcher recognizes different content when analysing images. The complexity of images functions in tandem with the concept of their general unattainability. This is why they cannot be used to set interpretations in stone. In fact, they serve as generators of diverse meanings 
and interpretations about 'other' cultures or 'one's own' culture. Thus, following Winfried Fluck (1997), this is exactly the potential of the cultural imaginary, and the means by which the researcher socially generates, passes on and transforms ideas:

The indetermination, the insatiability and the inexhaustibility of the imaginary become the starting point for a process of permanent re-design. [...] For it is the plus of the imaginary that transforms reality into possibility, in order to create a new reality from imagined possibility. With this in mind, the analysis of the cultural imaginary refers to the aspect of human existence, which is reality-constituting - precisely because of the often criticized unreal dimension. This aspect proves to serve as a recurrent impulse for redefinitions of "reality" which include far-reaching institutional and social consequences. (Fluck, 1997: 21)

Moving away momentarily from common sense theory, an observable potential of videography that has not been considered so far, aside from its capacity to create ambiguous images of other cultures, is that it can generate creative criteria for describing cultures, while simultaneously preparing them for analysis. Videography, thus, catalyses and enhances the development of cultural theory. However, it is necessary to aim beyond the current quantitative practices of video taking into education sciences:

Video is often pushed as a research tool in terms of its virtues of being an efficient way of telling a story ('a picture is worth a thousand words') and its utility as a data-recording tool (providing opportunities for multiple coding, slowing down action, etc.). These claims are true, but leave something out: video can be very pleasurable, both to make and to watch. These need not to be guilty pleasures. Why not name and acknowledge them? (Tobin and Hsueh, 2007: 90)

Based on this idea, the current paper investigates 'culture' as a potential differentiating category in videography, requesting details of the potential of videography for cross-cultural comparative studies. From here, the possibilities that arise when taking into account how analysing visual material not only explains national or cultural differences, but also contributes to the development of cultural theory itself are considered.

\section{Culture as a potential differentiating category in videography - a critical view on comparative cross cultural studies}

This project takes up the idea of the ambiguous potential of pictures and videography as a starting point for the analysis of cross-cultural videos about learning, which aims to explain the cultural side of learning. The point of interest is the texture of the cultural imaginary observable in current school videos.

There are two main discourses addressing videography in schools. The first of these is class situations, which can be employed as a means to analyse (and produce) cultural difference. This includes evidence-based teaching research, which exists in large-scale inter-country comparative studies, such as PISA and TIMMS, where videography is analysed according to standardized and often quantitative factors. These studies focus on empirical aspects like teachers' and students' speaking time, to compare and interpret differences between nation-states as cultural differences.

The second discourse is concerned with the genesis of cultures of learning and explores how cultures of learning manifest through interactions. These research approaches can be subsumed within cultures of learning that focus on 'doing class/school' (see Bohnsack, 1989; Fritzsche and Wagner-Willi, 2013; Kolbe et al., 2008; Tobin and Hsueh, 2007). This approach clarifies that, by taking into account a genetic analysis of teaching processes, cultural concepts can be readily 
established on grounds other than at the traditional nation-state level. In this context a question is raised about how learning cultures develop. In particular, this relates to how teachers and students together (interactively and partly even confrontationally) create meaning. Culture is not a predefined category when understood in this way, but one that develops in accordance with practical employment. Therefore, in this context, it is asked: How do the objects of research produce culture? (E.g. a common understanding of meaning, in everyday interaction.)

The example which follows shows a learning culture in which the sovereignty of interpretation is subject to authority, the teacher. At the same time, this is a learning culture that is extremely sensitive to tumult or disturbances in the order established in class. It can thus be described as an ambivalent authoritarian learning culture, one that cannot be defined categorically. Its peculiarity is only apparent in the close and differentiated analyses of videographies. Therefore, it can be established that: culture relates to learning itself, and is not solely determined at the nation-state level (see Weiß, 2005). Consequently, cultural concepts unfold in relation to the process of establishing meaning; that is, as the products of knowledge. The next step would then be to enquire about sociogenesis, by investigating the spaces within experience that shape the modes by which meaning is created in a specific way.

For example, learning cultures in which students and teachers negotiate meaning through critical debate and learning cultures where sovereignty of interpretation works in conjunction with certain status or hierarchy, can be distinguished between. This approach does not rely on aspects of comparison established by the nation-state, but rather analyses the genesis of education as a means of (de-)construction of common categories of differentiation. To clarify, a video-based interpretation of a school lesson will serve as an example.

The first example shows a video sequence from a 10th grade class at the Ramja Public School Pusa Road, Delhi. The lesson was entitled 'People as a Resource'.

The video sequence shows a lesson in economics; supported by a PowerPoint presentation on a whiteboard, a female teacher works with pupils on the economic perspective of the topic 'People as a Resource', asking them to repeat her words chorally. She refers to various examples. Suddenly, there is a break in interaction, and at that very moment the teacher points to a circle on her PowerPoint slide that says 'People can move mountains', the atmosphere in the classroom becomes agitated and dynamic. Suddenly the pupils seem to pay more attention; they all start talking at the same time and some of them stand up. The teacher tries to calm them down by saying: 'One by one. One by one. One by one'. The pupils sit down again, but the agitation is still palpable.

Analysing this sequence, no clear understanding of what had happened was attained. How had this tumult evolved? In the reconstructive analysis of videography there is therefore a shift from 'what did happen?', to 'how did it happen?'. According to Karl Mannheim (1980), there is a switch from understanding (as a matter of course) to an interpretive approach (that needs to inquire what is going on there). An interpretation is given below, with the description of the social constellation that establishes the groundwork for the tumult.

The teacher points at a picture and traces the line of the circle with the message, 'People can move mountains'. This is directly followed by collective agitation among the pupils. Some of them suddenly get up from their chairs; one girl puts her foot on a chair, a boy leans on his table. The pupils move towards the teacher in a motion similar to a wave. In contrast to the pupils the teacher stays almost immobile, like a piece of furniture. Then she raises her hand, cuts the air with it like a knife, and says loudly: 'One by one. One by one. One by one'.

In contrast to a research method that measures the quality of lessons using videography, videography observing learning cultures (e.g. Kolbe et al., 2008; Wulf and Zirfas, 2007; Wulf et al., 2007) asks how pupils and teacher actually perform something physically. Thus, we are able to recognize a relationship between the image of the written words ('People can move mountains') and the 
mimetic imitation of this 'metaphor' in the physical presence of the responding pupils. Obviously, the 'metaphor' plays an agitating role and the teacher does not participate physically in the dynamic movement. She is stiff and rigid, and excluded from the newly formed collective. Her body language suggests she is somehow afraid of the dynamic that has evolved. She then ends the agitation with her gesture, saying 'One by one' repeatedly. She hereby addresses the students as individuals and asks them to reply one after the other.

\section{Empirical insights: how the complex structure of learning culture can be described as peculiarly incomplete}

According to Boehm (2006 a, b), by conducting videography and analysing taped material in terms of incidents where pupils do not clearly and unambiguously learn, and understanding or writing something down, the metaphoric quality of implicit knowledge can be noticed.

This vivid, implicit knowledge creates unfamiliarity and insecurity on a physical level, in response to fractures within the image. These fractures show that images are complex and ambivalent material that affords complex and uncertain insights into learning. The photograms show how the teacher's reaction is both authoritarian and ambivalent at the same time. She orders, 'One by one!'; in the same moment her body language suggests fear. Even the pupils react ambivalently. They retreat from the dynamic group and speak as individuals, but their body language continues to suggest agitation. The teacher, and the pupils try to affect order, but both are interested in restoring (e.g. reconstituting) it (see Klein and Sting, 2005; Soeffner and Raab, 2005).

The documentary character of videography enables access to simultaneous and sequential structures of social interaction. It affords a closer look at what happens simultaneously and what happens consecutively. In order to detect ambivalence, heterogenic and ambiguous aspects are necessary to relate the video sequences to one another. It then becomes obvious how non-verbal messages extend to verbal messages. Additionally, this analysis of simultaneous phenomena can be related to the sequential structure of the social (phenomenon). It can be asked: how is meaning being coordinated by consecutive, i.e. coordinated gestures, facial expressions? Only when simultaneous and sequential aspects of social occurrences are related, will there be access to the complexity of social order (see Bohnsack, 2009; Wagner-Willi, 2005). Returning to the example here, it is noticeable how pupils react to the metaphor, and how the teacher tries to regain control, while also acting with fear. The sequential structure of videography opens up access to the dynamic aspects of social order in class. When the analysis of videography extends beyond quantitative interest, it becomes possible to learn more about the complexity of social aspects in class. For example, the implicit structure is defined by a fascinating ambivalence of power and powerlessness.

\section{Metaphors and images in cross-cultural video studies}

This approach to videography can be termed a pedagogic anthropology of images (Belting, 2001). It focuses on the way pictures, mental images and body language interact in a classroom context, and create a specific culture of learning (see Gebauer and Wulf, 2003; Imdahl, 1994, 1996; Waldenfels, 2002, 2009). However, this approach has not been considered (significantly) in studies based on videography. Rather, videography often exclusively analyses 'successful' learning and teaching, being used to offer evidence of certain aspects to develop the quality of classes (Paul and Reusser, 2006). According to Joseph Tobin, the "eagerness of educational researchers to respond to calls for "evidence-based educational policy" [has worked, J.L.] to reduce rather than to raise the 
quality of research in education' (Tobin, 2007: 335); instead, 'Education researchers should try to stay above or outside the fray of pressure to change schools, and to describe and understand these pressures rather than to be a part of them' (Tobin, 2007: 337). This would permit the genesis of cultures of learning to be described and analysed. In this case mental images (e.g. specific ideas about learning) would be of particular relevance. Therefore, researchers are urged to become aware of the ambiguity of images and the potential of videographies. It is important to evaluate videography beyond the level of common sense theory, include new aspects of research on learning cultures and render the complexity of social interaction accessible. Only then can teachers be aware of their own mental images and develop them (see Lamprecht, 2012, 2014, In press) and implement them in responsive studies.

\section{Imaginations of learning - the invisible in videography}

Learning theory states that everything that can be detected as 'learning' - as in videography simultaneously demands an invisible idea or imagination of learning processes. To declare a phenomenon as 'learning', it is necessary to obtain an idea of learning processes, which themselves are invisible, i.e. implicit. Especially in the field of video-based analyses, which focuses on the visible and the process of something becoming visible, it seems important to discuss the invisible aspects of learning; the moment when learning happens.

At the beginning of a video based research study, a researcher might want to question their notions about the learning process: Do I assume an effective or a disturbing learning process, and do I expect certain images accordingly? What do I consider an appropriate learning outcome, and which invisible and implicit process do I assume? Alternatively: How do implicit ideas about the learning process influence the observation of learning outcomes? The following section discusses this question following the example of Wiesemann's (2006) study on the visibility of learning.

In her empirical approach to the pedagogic term 'learning', Wiesemann (2006) examines related aspects regarding the visibility of learning. She convincingly differentiates between cognitivist, constructivist, phenomenological and subject oriented concepts. She contrasts these ideas of learning with a learning theory that assumes learning as an 'ordinary school experience', and consequently investigates learning according to situationist understanding as social practice (Wiesemann, 2006: 173). It becomes evident at this point that the visibility of learning implies a theory encompassing subject or appearance from the outset. Hence, it is very interesting to analyse empirical presentations focusing on this aspect: When exactly does the entanglement of an individual's own ideas about learning, and their visibility or invisibility, become a topic of interest?

In her thick descriptions of video-based participatory observation of class situations Wiesemann shows how students comprehend mathematical content in a physical and sensory way:

Sonja remembers a sensual experience related to the drawing of a triangle and the associated question. A few days before, Kurt, the teacher, had shown the heights of a triangle using a big wooden triangle. He had fixed a rope with a stone weight first to one and then consecutively to all three sides of the triangle. Mila and Sonja now reconstruct this sensual memory of the operation that had been realized days ago in abstract terms. (Wiesemann, 2006: 177)

Wiesemann analyses the reconstruction process, referring to her five-step-categorization as physical, sensual learning. The terms used (e.g. 'Sonja remembers' or 'sensual memory' or 'Mila and Sonja ... reconstruct ... in abstract terms'), show Wiesemann's ideas about the learning processes; that is, she makes observations on the actions in the video. 
Videography apparently provokes researchers to declare something as visible that in reality simply corresponds with their ideas and mental images of learning, which thus remains invisible. Similar descriptions can be found in numerous video analyses of educational situations regarding teaching and learning processes (e.g. see Helmke, 2012). Helmke spoke of the so-called 'holistic character of the investigation of teaching' (Helmke, 2009: 340), while Christine Pauli and Kurt Reusser looked at comparative international studies and observed the following: 'They show that Japanese math classes, even compared to five different and in the international comparison successful countries, still show a special profile and are highly consistent with the didactic ideals of good education' (Pauli and Reusser, 2006: 781).

By surmising invisible processes from visible results, a learning term is created based on efficiency, which, in the current author's opinion, is being reinforced by use of videographies. This goes in tandem with a focus on the results of learning and corresponding ideas about learning processes. However, from a phenomenological standpoint, it neglects 'traditions which look at learning from another perspective but result-oriented empirical research restricted to visible behavior' (Meyer-Drawe, 2008: 31). Therefore, it should be asked: What does video analysis display that it cannot also portray? How can imagination and ideas be distinguished from what is presented visually?

'The modus operandi [of any researcher as well as of the subject of research], in this imagery the field of imaginations and ideas, is the product of mental images and non-theoretic stocks of knowledge' (Bohnsack, 2014a, b; Waldenfels, 2002). This quotation emphasizes that it is important to point out that not only can we analyse the images that the researchers create based on their implicit knowledge and mental images, but we can also reconstruct ideas about the objects of research, in the example here the pupils and their teacher. Of course, the category of experience is an important aspect of the analysis. So it should then be asked: Which experiences of the researchers or the objects of research are emphasized as relevant in the video? And how is something learned about the mental images of the researcher and the objects of research? The ideas concerning research objects are displayed in particular situations when something does not work out or when certain mental images or concepts undergo a disturbance. In this example, it is the fact that the pupils reacted to the metaphor with an unexpected tumult and the teacher losing control of the situation. Those images become accessible when the phenomenological category of the 'fragility of experience' is referred to.

Another, still unacknowledged potential of videography would be the fragility of experience, which hints at a dynamic that first becomes relevant on a physical level. The video-based analysis of interruption in the continuity of a lesson might be interpreted as a 'Widerfahrnis' (Waldenfels, 2002); something that 'appears before it is perceived, understood or rejected. The experience of the disturbance must not be mistaken for the later interpretation as a disturbance and the following acts of defence, with which we re-gain our self-control' (Waldenfels, 2002: 33). This pre-reflexive disturbance makes mental images or ideals accessible (Foltys and Lamprecht, 2008a, b).

The teacher, who was reassuring that there are usually no such tumults in class, was displaying her implicit ideal of a good teacher and a good lesson. With a video based responsive conversation she might become aware of the implicit idea or image and reflect on it. It is again necessary to return to the question of cultural theory, which is intertwined with the relationship between mental or implicit and actual or material images of an individual's 'own' culture or 'other' culture.

In the example here, the cultural concept stands for a specific dynamic within a learning culture that has emerged due to the use of metaphors in class. The teachers' status is questioned, as the situation gathers momentum. The next question is how other learning cultures are led by, or irritated by, metaphors and images. However, what is the other 'culture' that can serve as a proper object of comparison? This question leads to the last point, which concerns cultural theoretical reflections. 


\section{On the potential of visual data material for the development of cultural theory}

The qualitative research of the lecture group 'Presence and implicit knowledge', where this study had its genesis, goes hand in hand with an understanding of culture as a coherent system, which (as Ernst and Paul believe), 'focuses on the microstructural dimensions of culture-specific patterns. Hence analysis needs to be realized on a subnational and subcultural level' (Ernst and Paul, 2013: 19). In order to meet the requirements of this paper, it makes sense to choose a cultural concept that implicates knowledge as a meaning-oriented approach (see Reckwitz, 2006). The chosen concept is 'collectively shared patterns of meaning and sense, a knowledge order which options action forms as one culture' (Reckwitz, 2006).

In the example here, culture is seen as a process whereby meaning and sense are yet to be created. It can now be asked: What formed this learning community? Which experiences and which fractures in their experience created the implicit guidelines that the teacher and the pupils follow? Therefore, the experiential spaces of the research objects according to the sociology of knowledge were analysed. In turn, we want to know: What kinds of experiential spaces generate what kind of knowledge? What makes the teacher stick to her professional behaviour? Which experiences made her perceive the pupils' autonomy as a threat and to do her best to address them as a group, and thereby return to conventions? Is it gender specific knowledge that drives her? Or does it have to do with a certain attitude of her generation? Instead of interpreting her behaviour exclusively as determined by her nation-state affiliation, social categories of differentiation that brought about this or other learning cultures, like sex, generation, milieu and others can be distinguished between (Bohnsack, 2007, 2009; Nohl, 2009; Schriewer, 2000; Weiß, 2002, 2005). Yet in current research, these dimensions and variables are not points of interest; however, according to Christel Adick they, 'might limit the focus on educational development, because the verifiable variables of the educational system are generally designed as interdependent variables and therefore do not consider characteristics such as relative autonomy of educational processes and learners justice' (Adick, 2005: 249).

In the empirical example given in this paper, the autonomy of the educational processes and learning justice consists of showing how an abrupt change in interaction happens that cannot be immediately understood. Initially it might be concluded that it is a cultural phenomenon that lessons are well ordered and linear. Obviously, the impulse for the discussion was not to come from the image that evoked a divergent, and therefore creative, multi-perspective, but from the teacher, who provides a convergent process. That this is not a New Delhi-phenomenon becomes obvious when analysing similar situations taking place in secondary schools in Munich. There was for example a geography lesson, which did occur the way the teacher had intended it to. The teacher prepared a YouTube video, which the pupils interpreted completely differently. There was a similar tumult, which also portrayed an ambivalent authoritarian learning culture in its linguistic and physical genesis (see Lamprecht and Ulrich-Riedhammer, 2014).

\section{Concluding remarks}

Notions about the seductive quality of images and metaphors in class, and their relationship to implicit or mental images cannot, therefore, simply be understood as national-cultural results, but rather as sub-national phenomena associated with current 'cultures of learning' in schools, that are becoming more and more important considering with the omnipresence of images and their use in various school subjects (see Lamprecht and Ulrich-Riedhammer, 2014). Thus, 'a comparative method' is suggested, that makes comparison the topic of discussion, and displays its potential and limits as a method with which to analyse certain aspects with scientific interest (see Schriewer, 2000). This paper presents a comparative theory emphasizing learning cultures as a 
collective process in the creation of meaning and sense. Learning is thus treated as a cultural phenomenon, whereby national and cultural differences are taken into account in terms of their validity. They can be used as socially differentiating, and hence, discriminating categories that need to be examined. (see Bohnsack, 2010; Bohnsack and Nohl, In press; Fritzsche, 2012; Fritzsche and Wagner-Willi, 2013).

\section{Funding}

This study is funded by the German Research Foundation.

\section{Notes}

1. In reference to geographical localization the following is added: the three public schools are located in Central Delhi, Safdarjung Enclave and Rohini West; the Government Aided School for boys is located in Paharganj, and the Government Aided School for girls is located in Darya Ganj. Public Schools in Delhi charge varying school fees that need to be paid by the pupils (their parents). This is common practice in India. Pupils who go to a Government Aided School do not need to pay school fees, meaning their parents do not need to cover the costs, as the schools are subsidized by the state. This specific structure brings about a certain selectivity concerning the social status of pupils' parental homes. Thus, pupils at Public Schools usually have an economically strong and educated background, whereas pupils at Government Aided Schools typically come from economically weak and educationally disadvantaged families. The research design for Delhi, therefore, includes three co-educational Public Schools and one Government Aided School for boys and girls, with the focus on secondary education (classes of 8-10 pupils, aged 13-15).

2. In reference to the process of data collection, it should be mentioned that a team of scientists from the Free University of Berlin, chaired by Professor Ralf Bohnsack, visited three types of schools: three public schools; a state school for boys; and a government supported school for girls. In all three schools, videography was undertaken during the teaching of different school subjects. The researchers were interested in how lessons happen. During the pilot study they also collected data at two secondary schools in Bavaria, in order to experience teaching from contrasting perspectives.

\section{References}

Adick C (2005) Transnationalisierung als herausforderung für die international und interkulturell vergleichende erziehungswissenschaft. Tertium Comparationis 11(2): 243-269.

Belting H (2001) Bild-Anthropologie. Entwürfe für eine Bildwissenschaft. Munich: Fink.

Boehm G (2006a) Die Wiederkehr der bilder. In: Boehm G (ed.) Was ist ein Bild? Munich: Fink, pp. 11-39.

Boehm G (2006b) Die bilderfrage. In: Boehm G (ed.) Was ist ein Bild? Munich: Fink, pp. 325-344.

Bohnsack R (1989) Generation, Milieu, Geschlecht. Ergebnisse aus Gruppendiskussionen mit Jugendlichen. Opladen

Bohnsack R (2007) Rekonstruktive Sozialforschung. Einführung in qualitative Methoden. Opladen and Farmington Hills: Barbara Budrich.

Bohnsack R (2009) Qualitative Bild- und Videointerpretation. Opladen and Farmington Hills: Barbara Budrich.

Bohnsack R (2010) Die mehrdimensionalität der typenbildung und ihre aspekthaftigkeit. In: Ecarius J and Schäffer B (eds) Typenbildung und Theoriegenerierung. Methoden und Methodologien qualitativer Bildungs- und Biographieforschung. Opladen and Farmington Hills: Barbara Budrich, pp. 47-72.

Bohnsack R (2014a) The interpretation of pictures and the documentary method. In: Hughes J and Goodwin J (eds) Documentary and Archival Research, Volume 2: Analysing Human Documents. Thousand Oaks, London and New Delhi: Sage.

Bohnsack R (2014b) Documentary method. In: Flick U (ed.) SAGE Handbook of Analyzing Qualitative Data. Thousand Oaks, London and New Delhi: Sage, pp. 217-233. 
Bohnsack R (In press) Körperpraxis und Körperimagination in der Fotointerpretation. In: Gugutzer R, Klein $\mathrm{G}$ and Meuser M (eds) Handbuch Körpersoziologie, Bd. 2. Wiesbaden: VS-Verlag.

Bohnsack R and Nohl A (In press) Komparative analyse und typenbildung in der dokumentarischen methode. In: Cappai G, Shimada S and Straub J (eds) Kulturanalysen. Kulturelle Praktiken vergleichen und verstehen. Bielefeld.

Dinkelaker J and Herrle M (2009) Erziehungswissenschaftliche Videographie. Wiesbaden: VS-Verlag.

Ernst C and Paul H (2013) Präsenz und implizites wissen. Zur interdependenz zweier schlüsselbegriffe der kultur- und sozialwissenschaften. In: Ernst $\mathrm{C}$ and Paul H (eds) Präsenz und Implizites Wissen. Zur Interdependenz Zweier Schlüsselbegriffe. Bielefeld: transcript Verlag, pp. 9-35.

Foltys J and Lamprecht J (2008a) Geburt - ein familiales Ereignis?In: Wulf C et al. (eds) Geburt in Familie, Kliniken und Medien. Eine qualitative Studie. Opladen: Barbara Budrich, pp 19-33.

Foltys J and Lamprecht J (2008b) Geburt und familie. In: Wulf C, Hänsch A and Brumlik M (eds) Das Imaginäre der Geburt. Praktiken, Narrationen und Bilder. Munich: Fink, pp. 136-148.

Fluck W (1997) Das Kulturelle Imaginäre. Eine Funktionsgeschichte des Amerikanischen Romans 17901900. Frankfurt/Main: Suhrkamp.

Fritzsche B (2012) Das Andere aus dem standortgebundenen bilde heraus verstehen. Potenziale der dokumentarischen methode in kulturvergleichend angelegten studien. Zeitschrift für Qualitative Forschung 13(1/2): 93-109.

Fritzsche B and Wagner-Willi M (2013) Ethnografie und videografie in praxeologischer perspektive. In: Loos P, Nohl A-M, Przyborski A et al. (eds) Dokumentarische Methode. Grundlagen - Entwicklungen - Anwendungen. Opladen: Budrich, pp. 268-287.

Gebauer G and Wulf C (2003) Mimetische Weltzugänge: Soziales Handeln - Rituale und Spiele - Ästhetische Produktionen. Stuttgart: Kohlhammer.

Helmke A (2009) Unterrichtsqualität und Lehrerprofessionalität. Diagnose, Evaluation und Verbesserung des Unterrichts. Seelze: Klett-Kallmeyer.

Helmke A (2012) Unterrichtsqualität und Lehrerprofessionalität. Diagnose, Evaluation und Verbesserung des Unterrichts. Seelze: Klett-Kallmeyer.

Hüppauf B and Wulf C (eds) (2009) Dynamics and Performativity of Imagination: The Image Between the Visible and the Invisible. New York, London and New Delhi: Routledge.

Imdahl M (1994) Bilder und ihre Anschauung. In: Böhm G (ed.) Was ist ein Bild? Munich: Fink, pp 300-324. Imdahl M (1996) Giotto - Arenafresken. Ikonographie - Ikonologie - Ikonik. Munich: Fink.

Kant I (1790/1998)Kritik der Urteilskraft (hrsg. v. Weischedel, Wilhelm). Werke in sechs Bänden, Bd. V: Kritik der Urteilskraft und Schriften zur Naturphilosophie. Darmstadt: Wissenschaftliche Buchgesellschaft.

Klein G and Sting S (2005) Performance als soziale und ästhetische Praxis. Zur Einführung. In: Klein G and Wolfgang S (eds) Performance. Positionen zur zeitgenössischen szenischen Kunst. Bielefeld: Transcript Verlag, pp. 7-25.

Kolbe F, Reh S, Fritzsche B et al. (2008) Lernkultur: Überlegungen zu einer kulturwissenschaftlichen Grundlegung qualitativer Unterrichtsforschung. Zeitschrift für Erziehungswissenschaft 11(1): 125-143.

Lamprecht J (2012) Rekonstruktiv-responsive Evaluation in der Praxis. Neue Perspektiven Dokumentarischer Evaluationsforschung. Wiesbaden: VS-Verlag.

Lamprecht J (2014) ErzieherInnen und LehrerInnen im Austausch. Videoanalysen zur Sinnkomplexität interaktiver Körperlichkeit. In: Bohnsack R, Baltruschat A, Fritzsche B et al. (eds) Dokumentarische Videound Filminterpretation. Methodologie und Forschungspraxis, Opladen: Barbara Budrich, pp. 97-111.

Lamprecht J (In press) Bildsprache - Sprachbilder: Eine empirische Studie zu neuen Führungskulturen im Übergang vom Elementar- in den Primarschulbereich. In: Stenger U, Edelmann D and König A (eds) Erziehungswissenschaftliche Perspektiven in frühpädagogischer Theoriebildung und Forschung. Weinheim andund Basel:Beltz-Juventa.

Lamprecht J and Ulrich-Riedhammer M (2014) Urteilsbildung und einbildungskraft. Zum fremden im geographieunterricht. In: Schoberth I (ed.) Urteilen lernen II. Ästhetische, politische und eschatologische Perspektiven moralischer Urteilsbildung im interdisziplinären Diskurs. Göttingen: Vandenhoeck and Rupprecht, pp. 89-124.

Mannheim K (1980) Strukturen des Denkens. Frankfurt/Main: Suhrkamp [unpublished manuscripts 1922-1925]. Meyer-Drawe K (2008) Diskurse des Lernens. Munich: Fink. 
Michaels A and Wulf C (2011) Images of the Body in India: South Asian and European Perspectives on Rituals and Performativity. London, New York and New Delhi: Routledge.

Nohl A (2009) Der Mehrebenevergleich als Weg zum kontextuierten Ländervergleich. Methodologische Überlegungen anhand eines internationalen Projekts zur Migrationsforschung. In Hornberg S et al. (eds) Beschreiben - Verstehen - Interpretieren: Stand und Perspektiven International und Interkulturell Vergleichender Erziehungswissenschaft in Deutschland. Münster, Munich [and others]: Waxmann, pp.95-110.

Pauli C and Reusser K (2006) Von international vergleichenden video surveys zur videobasierten Unterrichtsforschung und -entwicklung. Zeitschrift für Pädagogik 52(6): 774-798.

Reckwitz A (2006) Die Transformation der Kulturtheorien. Zur Entwicklung eines Theorieprogramms. Weilerswist-Metternich: Velbrück Wissenschaft.

Schriewer J (2000) Stichwort: Internationaler vergleich in der erziehungswissenschaft. Zeitschrift für Erziehungswissenschaft 3: 495-515.

Soeffner H and Raab J (2005)Körperlichkeit in interaktionsbeziehungen. In: Schroer M (ed.) Soziologie des Körpers. Frankfurt am Main: Suhrkamp, pp. 166-189.

Stenger U and Fröhlich V (2003) Das Unsichtbare Sichtbar Machen. Bildungsprozesse und Subjektgenese durch Bilder und Geschichten. Weinheim/Munich: Juventa.

Tobin JJ (2007) An anthropologist's reflections on defining quality in education research. International Journal of Research \& Method in Education 30(3): 325-338.

Tobin JJ and Hsueh Y (2007) The poetics and pleasures of video ethnography of education. In: Goldman R (ed.) Video Research in the Learning Sciences. New York: Lawrence Erlbaum Associates, pp. 77-92.

Waldenfels B (2002) Bruchlinien der Erfahrung. Frankfurt am Main: Suhrkamp.

Waldenfels B (2009) Das Unsichtbare dieser Welt oder: Was sich dem Blick entzieht. In: Bernet R and Kapust A (eds) Die Sichtbarkeit des Unsichtbaren. Munich: Fink, pp. 11-29.

Wagner-Willi M (2005) Kinder-Rituale zwischen Vorder- und Hinterbühne: Der Übergang von der Pause zum Unterricht. Wiesbaden: Springer VS.

Weiß A (2002) Raumrelationen als zentraler Aspekt weltweiter Ungleichheiten. Original in German Contribution by Mittelweg 36 (C) Mittelweg 36. Available at: www.eurozine.com (accessed 2015).

Weiß A (2005) The transnationalization of social inequality: Conceptualizing social positions on a world scale. Sociology 53: 707.

Wiesemann J (2006) Die Sichtbarkeit des Lernens - eine empirische Annäherung an einen pädagogischen Lernbegriff. In: Cloos P and Thole W (eds) Ethnographische Zugänge. Professions- und adressatInnenbezogene Forschung im Kontext von Schule und Sozialer Arbeit. Wiesbaden: VS-Verlag, pp. 171-183.

Wulf C and Hüppauf B (2006) Einleitung. Warum die Bilder die Einbildungskraft brauchen. In: Wulf C and Hüppauf B (eds) Bild und Einbildungskraft. Munich: Fink, pp. 9-47.

WulfC and Zirfas J (eds) (2007) Pädagogik des Performativen. Theorien, Methoden, Perspektiven. Weinheim/ Basel: Juventa.

Wulf C et al. (2007) Lernkulturen im Umbruch. Rituelle Praktiken in Schule, Medien, Familie und Jugend. Wiesbaden: VS-Verlag.

\section{Author biography}

Juliane Engel is assigned to the Institute of Pedagogy at the Friedrich-Alexander-University Erlangen and is interested in the development of a pedagogic anthropology of images. She is working on an empirical access for cross-cultural study on the invisibility of learning. Research and teaching interests include: cultural-historical study of imaging methods in pedagogy. 